Framework for General Practice. Available at www.health. gov.au/internet/wcms/publishing.nsf/Content/health-pubhlthabout-gp-snap-cnt.htm. Accessed September 2005.

13. NSW Health. NSW Chronic Disease Prevention Strategy: Discussion Paper. Sydney, Public Health Division, NSW Health, September 2001.

14. Kalucy E, Hann K, Guy S. Divisions: The network evolves: Report of the 2003-2004 Annual Survey of Divisions of
General Practice. Adelaide: Primary Health Care Research \& Information Service, Department of General Practice, Flinders University, and Commonwealth Department of Health and Ageing, 2005.

15. Australian Government Department of Health and Ageing. Lifestyle Prescriptions. Available at www.seniors.gov.au./ internet/wcms/Publishing.nsf/Content/health-pubhlth-strateglifescripts-index.htm, accessed 20 September 2005.

\title{
AN 'EVIDENCE CHECK' SYSTEM FOR FACILITATING EVIDENCE- INFORMED HEALTH POLICY
}

\author{
Danielle Campbell \\ The Sax Institute \\ George Rubin \\ Centre for Health Services Research \\ University of Sydney and Sydney West Area Health \\ Service
}

In partnership with the NSW Department of Health, the Sax Institute has established a Getting Research into Policy and Practice (GRIPP) Program to improve the integration of population health and health services research with policy. The program is overseen by the GRIPP Steering Committee, which is co-chaired by the NSW Chief Health Officer (Dr Greg Stewart until February 2005, then Dr Denise Robinson) and Professor Anthony Zwi (University of NSW). One initiative of the GRIPP Program is an Evidence Check system to facilitate the commissioning of high quality research reviews relevant to policy issues. This article outlines the background to Evidence Check and describes how the system was developed and implemented.

\section{BACKGROUND}

Reviews of Australian health research at both the national ${ }^{1}$ and state $^{2}$ levels have called for the establishment of priority-driven research programs supported by initiatives to improve the transfer of research findings into policy and practice. However, there are several known barriers to the integration of research and policy, including limited contact between researchers and policy makers, research that is untimely or not relevant to policy priorities, and the availability of competing forms of evidence of varying quality. ${ }^{3-5}$ It has been suggested that better exchange between the policy and research communities requires a cultural shift toward 'decision-relevance' in research and a 'researchattuned' approach to policy ${ }^{6}$, alongside the development of new organisational structures, improved linkage activities, and innovative human resource approaches. ${ }^{7}$

One strategy for encouraging the consideration of evidence in policy development is the production of targeted syntheses of research evidence relevant to policy issues. Such reviews can be useful in assembling the "evidence jigsaw' and highlighting the causal links that are relevant to policy decisions ${ }^{8}$, while avoiding some of the risks of relying on results from individual studies. ${ }^{9,10}$ Another strategy for promoting exchange between the research and policy communities is the use of knowledge brokers. Brokers are intermediaries who can foster relationships and facilitate communication between researchers and policy makers, so that the respective needs, values and priorities of both groups are considered..$^{11}$ The concept of knowledge brokering in public policy is not new ${ }^{12}$, but attempts to develop and evaluate the role in health contexts have emerged only recently. ${ }^{11}$

\section{THE EVIDENCE CHECK SYSTEM}

While these strategies are useful in theory, there is little empirical evidence to suggest how best to implement them in practice. Guided by expert members of the GRIPP Steering Committee and the experiences of groups such as the Canadian Health Services Research Foundation, the Evidence Check system was developed to facilitate access to high quality research reviews that could inform policy development across NSW Health.

Evidence Check has three components. First, an Evidence Check Commissioning Tool was developed, using the findings of a targeted literature review and consultations with senior policy makers and researchers about three hypothetical policy issues. The tool aims to elicit policy makers' needs so that an expert reviewer has the right information to produce a useful review. When completing the tool, policy makers are encouraged to act as 'intelligent customers ${ }^{13}$ of evidence by considering and articulating:

- the background to and purpose of the policy

- targeted questions to be answered by the review, including the intervention(s), population(s) and outcomes of interest

- the timeframe and funds available to conduct the review 
- the breadth of evidence to be considered and the depth of analysis required

- the format of the final product, with an emphasis on reader-friendly styles such as the 1:3:25 framework (see page 178 in this issue) developed by the Canadian Health Services Research Foundation. ${ }^{14}$

Second, a directory of experienced researchers from across NSW has been established. The directory will enable the timely identification of experts who have up-to-date knowledge of the most recent research evidence in their field, and the skills and capacity to conduct high quality reviews of the evidence.

Third, a team of knowledge brokers has been recruited. The brokers are senior health and social sector professionals with extensive experience in both the research and policy spheres and excellent negotiation and communication skills. As each review opportunity arises, a broker will be appointed to liaise between the policy maker and reviewer during the process of scoping and commissioning the review, and provide advice to all parties as required.

\section{CONCLUSION}

Evidence Check is currently being trialled across the NSW Department of Health. Findings from an ongoing evaluation will be built into the Evidence Check system to ensure it continues to work to the mutual benefit of policy makers and researchers in NSW.

For more information about Evidence Check visit the Institute's website at www.saxinstitute.org.au.

\section{REFERENCES}

1. Wills PJ, Armstrong AM, Bradshaw RA, Chalmers JP, Ewan $\mathrm{CE}$, Funder JW et al. The virtuous cycle: Working together for health and medical research. Health and medical research strategic review: Summary. Canberra: Commonwealth of Australia; 1998.

2. Wood GSR, Morstyn G, Whitworth J. NSW research: A prescription for health. Report of a review commissioned by the Minister for Science and Medical Research, The Hon Frank Sartor MP. Sydney: NSW Government; 2004.
3. Bowen S, Zwi AB. Pathways to 'evidence-informed' policy and practice: A framework for action. PLoS Medicine 2005; 2(7): e166.

4. Innvær S, Vist G, Trommald M, Oxman A. Health policy makers' perceptions of their use of evidence: A systematic review. J Health Serv Res Policy 2002; 7(4): 239-44.

5. Lavis J, Davies H, Oxman A, Denis J-L, Golden-Biddle K, Ferlie E. Towards systematic reviews that inform health care management and policy making. J Health Serv Res Policy 2005; 10 Suppl 1: S35-48.

6. Lavis J, Ross S, McLeod C, Gildiner A. Measuring the impact of health research. J Health Serv Res Policy 2003; 8(3): 165-70.

7. Lomas J. Improving research dissemination and uptake in the health sector: Beyond the sound of one hand clapping. Hamilton, Canada: McMaster University Centre for Health Economics and Policy Analysis; 1997.

8. Whitehead M, Petticrew M, Graham H, Macintyre SJ, Bambra $\mathrm{C}$, Egan M. Evidence for public health policy on inequalities. (2) Assembling the evidence jigsaw. J Epidemiol Community Health 2004; 58(10): 817-21.

9. Lavis JN, Robertson D, Woodside JM, McLeod CB, Abelson J, the Knowledge Transfer Study Group. How can research organizations more effectively transfer research knowledge to decision makers? Milbank Q 2003; 81(2): 221-48.

10. Sheldon TA. Making evidence synthesis more useful for management and policy making. J Health Serv Res Policy 2005; 10 Suppl 1: S1-5.

11. Canadian Health Services Research Foundation. The theory and practice of knowledge brokering in Canada's health system. Ottawa: Canadian Health Services Research Foundation; 2003.

12. Sundquist JL. Research brokerage: The weak link. In: Lynn LE, editor: Knowledge and policy: The uncertain connection. Washington: National Academy of Sciences; 1978. 126-44.

13. Cabinet Office. Professional policy making for the twenty first century. Report by the strategic policy making team in the Cabinet Office. London: Cabinet Office; 1999.

14. Canadian Health Services Research Foundation. Communication notes. Reader-friendly writing-1:3:25. Ottawa: Canadian Health Services Research Foundation; 2003. Available from:_www.chsrf.ca/knowledge_transfer/ pdf/cn-1325_e.pdf. 